\title{
Progress in Controlling Inflation
}

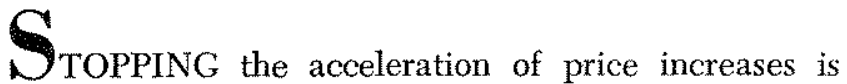
currently the most important objective of national economic policy. The other major objective, "full employment" defined as an unemployment rate below 4 per cent, has been achieved since late 1965. The method that has been chosen to achieve stable prices is to curtail growth in total spending (GNP). Historically, a slowing of total spending has been accompanied by a slowing in the growth of real product, followed by a slowing in the rate of increase in prices and by subsequent recovery in the growth rate of real product. Consequently, the question arises as to what is implied for the course of real product under the current anti-inflation policy.

\section{The Current Anti-Inflation Program}

Economic developments in 1969 are proving that historical patterns of output and prices are reliable guides for any assessment of the success of the present anti-inflation program. Total spending for goods and services rose at a 7.8 per cent annual rate from mid1968 to the third quarter of this year, less than the 9.6 per cent increase in the previous year but still far in excess of the growth rate of the economy's productive potential. Prices have advanced at a 4.8 per

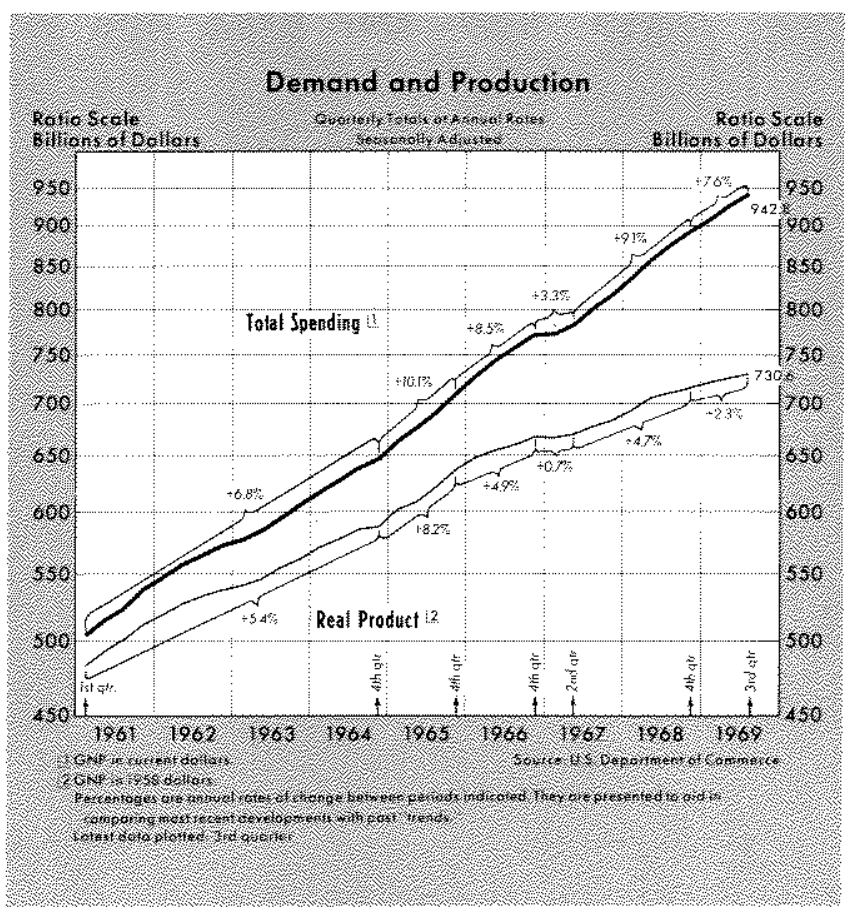

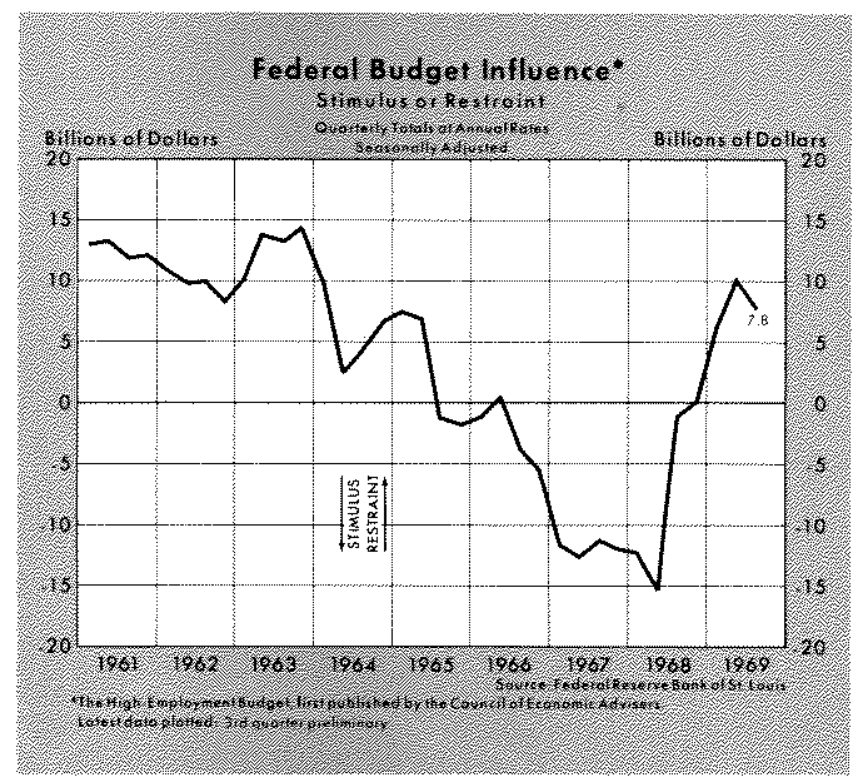

cent rate since mid-1968, a much faster rate than in the previous year. Real output, on the other hand, increased at only a 2.8 per cent rate over the past five quarters, down from the 5.3 per cent increase in the year ending in mid-1968.

Final sales have slowed somewhat since mid-1968, but their growth continues at a relatively rapid rate. These sales grew at an 8.8 per cent rate from mid1967 to mid-1968 and since mid-1968 have increased at a 7.8 per cent annual rate.

\section{Fiscal Conditions}

Federal fiscal policy has continued restrictive in its impact on economic activity since mid-1968, when the Revenue and Expenditure Control Act of 1968 was passed. On a high-employment basis, the national income accounts budget was in surplus at a $\$ 7.8$ billion annual rate in the third quarter, down slightly from the previous two quarters, but in marked contrast to the $\$ 13.7$ billion annual rate of deficit in the first half of 1968. This shift of the budget from a large deficit to substantial surplus was accomplished by a sharp reduction of expenditure growth and enactment of the 10 per cent tax surcharge.

Federal expenditures have risen at a 5.9 per cent annual rate since mid-1968, compared with a 11.7 per cent increase in the previous year. Defense spending has slowed markedly, rising at only a 2.8

Page 2 
per cent rate since mid-1968, compared with a 13.9 per cent average rate of increase during the period from 1965 to 1968 .

Budget prospects for calendar 1970 indicate that the overall fiscal restraint will continue at least through the first half. Current estimates include restriction of the rate of growth in Federal expenditures at a 3 per cent rate until at least mid-1970. The tax program includes a reduction of the tax surcharge to 5 per cent on January 1,1970 and repeal of the investment tax credit retroactive to April 20, 1969. If these expenditure and taxing expectations are realized approximately, the degree of fiscal restraint will continue through the first half of 1970 , with the highemployment budget at an estimated $\$ 9$ billion rate of surplus. If, on the other hand, the surtax is allowed to expire at the end of this year, this budget would be at an estimated $\$ 5$ billion rate of surplus in the first half of 1970 .

While the high-employment budget suggests continuation of the current posture of fiscal restraint in early 1970 , the degree of restraint may be greater than this budget suggests. Consumers and businesses, to some degree, react to changes in tax rates, which they consider to be temporary, by adjusting their rate of saving rather than their spending. As a result, changes in tax rates are significant in the short run because they signal a change in the allocation of resources between the Government and the private sector. According to this interpretation, the expected course of Federal spending, rather than the net budget position, may in fact provide a more reliable indication of the degree of fiscal restraint in the near future.

\section{Recent Monetary Actions}

Monetary actions became moderately less expansive early in 1969, and since early summer a considerable degree of restraint has been exercised. The money stock has been about unchanged in the last four months, compared with a 4.4 per cent annual rate of growth in the first half of the year and a 7 per cent increase in 1968. The demand deposit component of money declined at a 1.2 per cent rate from June to October, after decelerating from a 7 per cent increase in 1968 to a 3.7 per cent rate of growth in the first half of 1969.

The monetary base, uses of which are total bank reserves and currency held by the public, has increased only slightly since early june. The money stock and the monetary base usually grow at similar rates, as in 1968 when they both grew 7 per cent, and

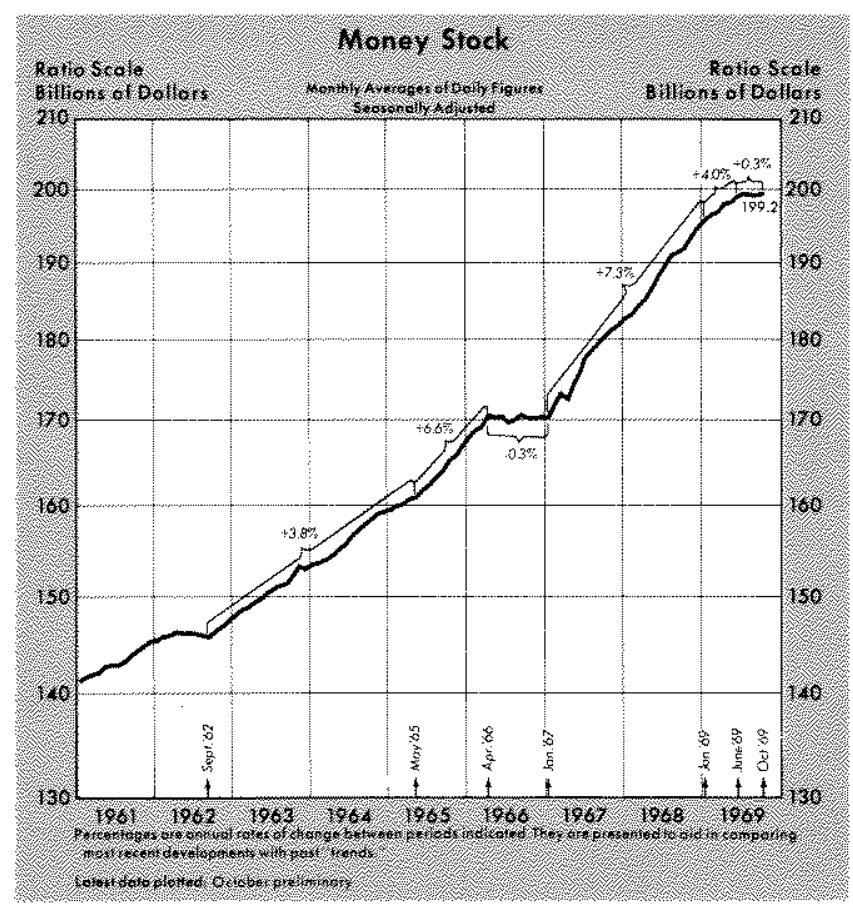

in the last three months when they have both been about unchanged. However, small shifts frequently occur in the multiplier relationship between the monetary base and money. ${ }^{1}$ Since early June, the continuing outflow of time deposits from commercial banks has been a major factor causing a net increase in the multiplier. Federal Reserve credit increased at only a 0.8 per cent annual rate from June to October, after increasing at a 6 per cent rate in the first part of the year and 10 per cent in 1968. Member bank reserves declined at about a 9 per cent annual rate from June to October, after being about unchanged during the first part of the year, and growing 8 per cent in 1968.

Interest rates have risen recently, though most rates are still below early October peaks. Over the past year interest rates have increased markedly, with yields on prime four- to six-month commercial paper rising about 3 percentage points. In contrast, Regulation $Q$ ceilings have remained unchanged, and the discount rate has been increased only three-fourths of a percentage point during the past year. The discount rate is currently about one percentage point below the three-month Treasury bill rate, compared with a spread of about one-fourth of a percentage point a year ago.

Volume of commercial paper outstanding has continued to increase rapidly, up $\$ 7.8$ billion since last

ISee Jerry L. Jordan, "Elements of Money Stock Determination," this Review, October 1969, pp. 10-19. 
December, compared with a $\$ 3.4$ billion increase in the corresponding period of 1968. In contrast, the outstanding volume of large negotiable certificates of deposit at large commercial banks declined by $\$ 12.1$ billion from last December to October 1969. Low Regulation $Q$ ceilings relative to market rates have prevented banks from competing effectively for funds, thereby directing funds through other chamels such as the commercial paper market. Whether the rerouting of funds from commercial banks through other channels is an indication of monetary restraint is doubtful. It is clear, however, that the rerouting of funds promotes inefficiences in the channeling of funds from savers to investors.

\section{Economic Conditions}

Total spending, that is, nominal GNP, continued to grow from the second to the third quarter at about the same rate as in the three previous quarters, despite the restrictive position of monetary and fiscal policy. The composition of the increase in total spending in the third quarter, however, indicates a slowing of total spending might be expected in the immediate future.

Though total spending continued to advance at a rapid rate, private final sales rose much more slowly in the third quarter. Total spending was buoyed by increases in the rate of inventory accumulation and the Government pay increase. If these increases are not indicative of a trend, the slowing of private final sales may portend further slowing in the pace of economic activity.

Measures of income, employment and production indicate that there was some slowing in the pace of economic activity during the third quarter. While this observation is based on a very short period, it is consistent with the restrictive nature of monetary and fiscal actions. Personal income slowed to a 4.8 per cent rate of increase in October, after rising at a 8.8 per cent rate in the January to September period. Payroll employment rose at a 2.4 per cent rate in the July to October period, compared with a 3 per cent rate in the previous six months. Industrial production, slowed by reductions in primary metals output, declined at a 2.9 per cent rate from July to October, compared with a 6.1 per cent rate of increase from December to July.

Conforming to the usual patterns of lags of price effects behind total spending, price trends have continued upward. The general level of prices rose at a 5.4 per cent annual rate from the second to the third quarter, compared with a 4.6 per cent increase in the previous year. Wholesale prices of industrial commodities have risen at a 3.7 per cent rate over the past year. Consumer prices have risen at a 6 per cent rate since the first of the year, compared with a 5 per cent rate in the previous year.

\section{Outlook for Prices and Output}

The current stabilization program is directed toward slowing total spending as the necessary means of limiting the advance of prices. Recent trends in income, employment and production suggest that this program of restrictive monetary and fiscal actions has begun to take effect, though as yet there has been no discernible effect on prices. Past experience, however, indicates that restraint in total spending has its effect first on output growth, and only later on prices. The rate of increase in output must be expected to slow, as an inevitable by-product of an anti-inflationary program. It is of interest, therefore, to trace out the possible course of real output during this transition period.

Total spending has decelerated only slightly since mid-1968. The restrictive economic policies should soon begin to affect demand growth significantly. The rather steady rate of demand growth has been accompanied by a slowing in the growth of real output and an acceleration in the rate of price increase.

To aid in the exploration of the outlook for the near-term, alternative growth rates of money and Federal expenditures can be postulated, and the most probable future movements in total demand, output and prices, projected on a basis of historical experiences, can be examined. The monetary and fiscal restraint that has already occurred provides the basis for substantial further slowing in output growth, and for gradual slowing in the rate of price advance. The choice of alternative rates of monetary expansion at this point (fourth quarter 1969) will be instrumental in determining the extent and duration of the slowing of total output. Prices can be brought down more rapidly by restricting growth in money severely, but with larger cost in terms of restriction of real output.

Monetary and fiscal restraints are probably being manifested in reduced total dollar demand and real output growth. The task of policymakers is to avoid a prolongation of a degree of restraint which would lead to excessive restriction of output growth, but at the same time to avoid a premature reversal of the policy of restraint such that significant progress would not be made in effectively reducing inflationary pressures. 